\title{
Securing Local Government Funds for National Development: An Overview
}

\author{
Anselem C. Nweke \\ Department of Public Administration \\ Anambra State University, Igbariam Campus \\ nwekeanselem@yahoo.com
}

\begin{abstract}
This paper interrogates the issue of securing local government funds for national development. Using traditional theory of fiscal federalism. It highlights the various sources of local government funds. It is basically a content analysis and all the materials are based on secondary sources of data generation. The paper observed that the degree of external influence and intrusion in local government funds by the state government is worrisome. Such external interference indeed subverts democratic process and undermines constitutional authority of the local government. The paper suggest the amendment of section 7 of the 1999 constitution that places local government under the state government, and recommends that local government should be granted full autonomy. The National Assembly should be the creating authority of local government as this will rightly place local government as the third tier of government with full direct allocation from federation account, direct and control over their respective localities.
\end{abstract}

Key words: securing, local government, funds, national development

\section{Introduction}

Nigeria got her independence in 1960 from the colonial master (British empire). It has witnessed different kinds of local government system as a result of the introduction of indirect rule by the British government. Until recent the unification of local government administration popularly know as the 1976 local government reform.

This reform and the 1979 constitution recognized local government as the third tier of government in Nigeria. Presently Nigeria is made up of 774 local government with constitutional assigned functions and responsibilities. The importance of local government is a function of its ability to generate sense of belongingness, safety and satisfaction among its populace. All forms of government, regimes both civilian and military have so far ensued the attainment of this goal. Such strategy for ensuring national development and political efficacy is found in the concept and practice of local government. Whatever is the mode of government, local government has been essentially regarded as the path to and guarantor of, national integration, administration and development.

Thus, in Nigeria's socio-political context, with multiplicity of culture, diversity of language and differentiated needs and means of achieving them, the importance of such on organization in fostering the uniformity as well as preservation of peculiar diversities cannot be over emphasized.

The main issue behind the creation of local government is to establish an avenue through which government and people intermix, at the grassroots collaborates for effective national development. 
Therefore, local government has been perceived as a panacea for the diverse developmental confronting Nigeria's diverse people with multiplicity of culture. As important as local government has been, there seems to be hindrances or impediments on the performance of its functions in recent times. These impediments range from bribery and corruption, misappropriation of funds and most importantly undue political interference of the higher levels of government that is associated with fiscal federalism. Thus, this paper looks at various sources of funds available to local government with the view to explore how best to secure them for national development.

\section{Conceptual Clarifications \\ Local Government}

It is defined as the level of government below the central government in the case of a unitary state, or below the Regional, provincial or state government in the case of federal state, which is obliged to provide a range of services set out by law, to its communities and has legal authority to do this.

In the words of Orewa (1991:24) the local government has its legal power to enforce its executive and regulatory decisions on its citizens without resorting to social pressures to achieve this. Its area of authority and the basis of representation on its political leadership platform are defined by its instrument it has its own staff.

Local government as the government nearest to the local people and is the third tier of government, set up to meet the needs and aspirations of the rural dwellers (Obi 2009:304)

Local government as far as Nigeria with a federation is concerned, is the third tier of government and the government nearest to the people irrespective of urban or rural communities.

\section{Funds}

Oxford Advanced Learners Dictionary defined fund as sum of money saved or made available for a particular purpose.

Funds are amounts of money that are available to be spent, especially money that is given to an organization or person for a particular purpose.

\section{National Development}

National development is the ability of a country or countries to improve the social welfare of the people e.g. by providing social amenities like quality education, potable water, transportation infrastructure, medical care etc.

It is development that is a general or specific who's goal is to help build up various areas within a nation (http://answers.ask.com). 
It also has to do with development in infrastructure such as roads, hospitals, airports, dams, schools etc. as well as development in its people.

\section{Theoretical Framework}

This paper adopts the "traditional" theory of fiscal federalism as its framework of analysis as developed by Davoodi and Zou, (1998); Clark and Van Wincoop (2001): Darby, Muscatelli, and Roy, (2002); De Mello, (2000); and Bahl and Linn, (1992). This theory of fiscal federalism according to its protagonists considers:

$>$ How best to provide public goods and services at the federal, state and local government levels;

$>$ How best to finance public spending at the federal, state and local government levels;

$>$ How to design a system that imposes hard - rather than soft, budget constraints on the lower tiers of government;

$>$ How best to provide for needs equalization between regions;

$>$ How to design a fiscal federal system that effectively stimulates economic growth;

The basic principle in the traditional theory of fiscal federalism is that the three levels of government should have the ability to provide goods and services that match the particular preferences and circumstances of its constituents. The key presumption is that the provision of public services should be located at the lowest level of government encompassing geographically the relevant costs and benefits. In that way efficiency and economic welfare can be increased above that generated by a more uniform allocation mechanism.

This 'benefit rule' is a standard yard stick for sharing the national revenue between the three levels of government suing rational decision. Issues whose benefits extend nationwide (or because there are economies of scale) are foreign affairs, defence and interregional infrastructure such as transport and telecommunications is allocated to the federal government with centralized provision. Some issues whose benefits are of regional or urban spread are allocated to the state with state provision while many other public issues that have are vocationally circumscribed such as the local/bush firs, street infrastructure, market infrastructure and spending on primary health and education, etc are allocated to the local government with local government provision.

Fiscal federalism therefore becomes the framework for re-distribution of national income to these levels of government for over all national development.

This framework of study enables this paper to study local government funding/sources of revenue and its constraints in Nigeria and asses it as a framework or instrument of national development.

\section{Sources of Local Government Funds}

Basically local government has two main sources of funding, which include

i. Internal sources

ii. External sources 
i. Internal Sources: It is the way through which the local government generate their funds internally. They are the sources through which local government generate their revenues through their own efforts (Nweke 2001).

Section 2.2 of the Model Financial Memoranda (1998:18) classified the internal sources of revenue generation in the following heads:

Head 1001: Taxes which include community, development, cattle and other special services (Electricity, water, night guards etc)

Head 1002: $\quad$ rates consist of tenement rate, ground rents, federal and state government grants in lieu of tenement rates.

Head 1003: $\quad$ Local licences, fees and fines are generated from bicycles, wheel barrows, marriage registration, general contractors registration. Approval of building plans and a host of others.

Head 1004: $\quad$ Earnings from commercial undertakings these sources generate revenue from markets, motor parks, shops, abattoir/slaughter houses, transport services etc.

Head 1005: Rents on local government property include local government quarters, buildings and landed property.

Head 1006: Interest and dividend payments are realized from vehicle and bicycle/motor cycle advances, loans to other local governments, staff housing and capital market respectively.

Head 1007: Miscellaneous consists of mortuary hearse and cementry, recovery of losses, unclaimed deposits, and over payment in lieu of registration notices.

Apart from the above, there are other internal arrangements made by some local government to generate more revenue. These include Guest houses, mass transit, poultry farm, agricultural form operation, convenience system, recreational centres etc.

ii. External Sources: This constitutes a major source of revenue to local governments in Nigeria. It comprise a statutory allocations from the federation account and $10 \%$ of the internally generated revenue of the state government (section 162 (7) of 1999 constitution), (Oyelakin 2004:11).

\section{Local Government Fund and Constitutional Provision}

The local government funds are not secured because of the way and manner in which the state governments handle local government funds. According to Shuaib (2006) pointed out that a lead judgment of the supreme court read by justice Niki Tobi, ruled that the federal government lacked the power to monitor the ways and manner in which state distribute funds to local governments in their jurisdictions. In fact the court further ruled that the representatives of the Revenue Mobilization Allocation And Fiscal Commission (RMAFC) in the state joint local government account committee were busy bodies who should find their way out. Justice Niki pointed out bluntly that "the national Assembly has not the legislative competence to legislate on the nicety or nitty-gritty of the allocation. 
"Any person who is at the corridors of local government finances or funds or sleeping with them and sees this judgment as a victory in the sense that he has freedom of the air to steal ... should think twice and quickly remind himself that the two anti-corruption bodies ... are watching very closely and will without notice pounce on him (or her) for incarceration after due process ... But that is not as serious as God's law which says he will go to hell and he will make hell. This is not a curse. God's law does not lie because God is not a liar". It is noteworthy that the justice knows the implication and delicacy of the judgment by making reference to our infallible holy scriptures, and indirectly points out the weakness of our law that may by some of its provisions, contradictorily promote vices within the system.

The state joint local government account (SJLGA) is not creation of the 1999 constitution but is an Act of National Assembly known as Allocation of Revenue (federation Account) Act 1981. That same Act established what is now know as Federation Account Allocation Committee (FAAC) which meeting is held every month since then. During the era of the military in our national life other Decree were enacted by the federal government like Decree 49 of 1989 which established for the federation (note the word "FEDERATION NOT FEDEGAL GOVERNMENT") the Revenue mobilization allocation and fiscal commission with powers to "monitor the accruals to and disbursement of revenue from the federation account". This specific power of RMAFC amongst other functions in that Decree is still sustained in 32(a-c) part 1 of the third schedule to the 1999 constitution (shuaib 2006).

He went further to argue, since military decrees, by law became Acts of the National Assembly with the advent of democracy, Decree 98 of 1993, an amendment to Decree 49 of 1989 which established the commission makes RMAFC a member of FAAC as well as SJLGA committees. It is interesting to note that while SJLGA is retained in the 1999 constitution, the FAAC is deleted, omitted, in a lighter word is missing.

\section{The Gross Abuse of the Constitutional Provision}

It is worthy of note that, the degree of external influence and intrusion in local government affairs by the higher levels of government is worrisome and needs re-evaluation. Situation where the state governor unconstitutionally dissolves the entire elected council's officers without proper investigations on spurious allegations is not good for the future of local government administration in Nigeria. Such external interference indeed subverts democratic process and undermines constitutional authority of the grassroots level.

The high point of the matter is the "almighty" power and misuse of it enjoyed by the state governments over local governments. Practically, and in true sense, local government in Nigeria lacks autonomous financial power. Local government is now considered as an extension of state's ministry. Thus, the inherent nature of this problem has caused subservience, a situation where local government waits for the next directives from state government before it could think of, let alone embarking on developmental projects. This has made local government an object of control and directives from the state government. Where goes the constitutional recognized third tier of government? 
However, the major challenge that local government faces is the political control by the state governor over the local government council. The fact is that most of the governors through the state Independence Electoral Commission (SIEC) delivers or sponsors election of most, if not all, of the councilors and chairmen. They are handpicked by the state governor rather than being elected. The worst of all, is the appointment of Transition Committee to run the affairs of local government by the state governor. All these create a problem of diversion of local government funds for personal use of the state governor. Let look at one or two study.

Ondo state - in Ondo state, there is this unholy alliance between state government and local councils in the state, where the state government constitutes Joint Action Committee, (JAC). Federal allocations to local government are first deposited into a particular adhoc account before calling for the committee meeting. This is a way the state government manipulates the local government and release the money in installments. The motive behind this is to divert the money to another thing entirely which does not have impact on the lives of the people but that will be beneficial to the state governor. Another thing is that local government chairmen who have genuine intentions to develop the council area are being discouraged. The implication of this is the negative impact it has on the people of the grassroots as they are getting more and more alienated from developments.

Anambra State - The worst of the state control of the local government, is that witnessed in Anambra state. The last local government election in Anambra State was conducted on December 1998. The life of this elected council lasted for three years. In other words from 2002 till date Anambra state governors are running the affairs of the local government in the state with caretaker committee or transition committee.

A look at the federal allocation to local governments in Nigeria between 1998 and 2008.

\section{Table 1}

Federal Allocation for Local Government in Nigeria 1998 - 2008 (Nbn)

\begin{tabular}{|l|l|l|l|l|l|l|l|l|l|l|}
\hline 1998 & 1999 & 2000 & 2001 & 2002 & 2003 & 2004 & 2005 & 2006 & 2007 & 2008 \\
\hline $\begin{array}{l}44.94 \\
8\end{array}$ & $\begin{array}{l}60.80 \\
1\end{array}$ & 151.877 & 171.523 & 172.151 & 370.171 & 468.295 & 597.219 & 647.256 & 832.300 & $\begin{array}{l}1,387.87 \\
1\end{array}$ \\
\hline
\end{tabular}

Source: Central Bank of Nigeria $(\mathrm{CBN})$ : Statistical Bulletin, 50 years special Anniversary Edition, December 2008

It was observed from the above table that the revenue allocations from the federal government to local government councils were increasing astronomically year by year. Example, there was increase in 1998 from N44.948 billion to 60.801 billion in 1999 and it keeps increasing year by year till 2008 to over 1.3 billion. The question is how can this funds that are accrued to the local government be secured for national development. It is imperative to understand that when the 774 local governments in Nigeria are developed the whole nation is developed.

Conclusively, the basic rational behind the creation of local government is to meet the basic needs of the people at the grassroots. Thus, when the basic needs of all the people in the 774 
local governments in Nigeria are provided, the basic needs of the nation is provided. That is "develop the local governments, develop the nation".

Then the questions are (1) where has the External funds for the development of 21 local governments in Anambra state from 2002 - date has gone? (2) Is local government truly third tier of government or a ministry under the state government?

\section{The Way Forward}

The suggestions of this paper are as follows:

- The major reason behind the creation of local government is to bring developments to the people. To do this effectively, there is need for local councils to have strong economic base. It is suggested that statutory allocations to local councils be reviewed upward. This will enhance the development and stability of the nation.

- Direct Federation allocation to local government. It is suggested that the shares of the federation account to be released to local government directly to avoid lateness in the payment of salaries, arbitrary deductions and embezzlement by state governor.

- Local government should have representation in the Revenue Allocation and Fiscal Commission, which determines and shares the federated revenue to the beneficiaries.

- State government must comply with the provision of the constitution, by making sure that they allocate 10 percent of their internally generated revenue to the local governments under their jurisdictions as empowered by section 162.7 of 1999 constitution. This is because of the fact that most state governments have defaulted in this regard, and refused bluntly to remit such to the local governments under them.

- Constitutional amendment. This paper as the most serious way of securing local government funds for national development, suggest, the amendment of section 7 of the 1999 constitution that places local government under the state government. Thus, the local government should be granted full autonomy that will reflect third tier of government. And being the nearest government to the people, it knows the developmental challenges facing the people. National Assembly should be the creating authority of local government with full direction and control over their respective localities. Election to the local government council should be conducted by Independent National Electoral Commission (INEC).

\section{References}

Bahl, R.W. and Linn, J.F. (1992), Urban Public financing in Developing Countries, Oxford University Press, Oxford.

Clark, T.E. and E. van Wincoop (2001), 'Borders and Business Cycles', Journal of International Economics, 55, 59-85

C.B.N. (2008), Central Bank of Nigeria Statistical Bulletins, 50 years Special Anniversary Edition December.

Cowie, A.P. (1989) (eds); Oxford Advanced Learners Dictionary of Current English. Britain: Oxford University Press. 
Darby, J., Muscatelli, A., and Roy, G. (2002), "Fiscal Federalism and Fiscal Autonomy: Lessons for the UK from Other Industrialized Countries", Scottish Affairs, No. 41, 2002, pp. 26-54.

Davoodi, H. and H. Zou (1998), "Fiscal Decentralization and Economic Growth A CrossCountry Study", Journal of Urban Economics, 43:244-257.

De Mello, L. (2000), 'Can Fiscal Decentralization Strengthen Social Capital' IMF Working Paper No 00/129, Washington DC.

Nweke, A.C. (2001), Financing Local Government Administration in Nigeria, a Case Study of Ayamelum. Unpublished B.Sc Project submitted to the Department of Political Science Nnamdi Azikiwe University, Awka.

Obi, M.A.O. (2009), A Critical Analysis of Project Conceptualization and Management in Nkanu Local Government in Enugu State", Nigeria journal at Public Administration and Local Government, University of Nigeria, Nsukka, Nos. 1 and 2 September.

Orewa, G.O. (1991) Principles of Local Government. Lagos: Administrative Staff Collage of Nigeria (ASCON)

Oyelakia, O.O. (2004), Implementation of the Federal Executive Presidential System of Government and its logic at the Local Government Administration and Bye Laws in Nigeria. Abuja: Joe freeman International Book Agency.

Shuaiba Y. (2006), Federation account and the last Judgment. Google Search. 